\title{
Education and linguistic boundaries in Québec: Student representations and pedagogical reflections from a critical perspective
}

\author{
Annie Pilote, Marie-Odile Magnan \& Cynthia Groff \\ Université Laval, Québec, Canada
}

(Article received 15 July 2011; final version received 24 August 2011)

\begin{abstract}
:
Relations between francophones and anglophones in Québec City reflect historical struggles and changing power relations between the groups. Using a constructivist and interactionist approach to identity and ethnicity, we examine the role of English language schools in intergroup relations. We present findings from two qualitative studies conducted with youth who attended English language schools in Québec City, showing how the school system contributes to the (re)production of linguistic boundaries. The boundaries evident between language groups, as illustrated in student drawings and memories, reflect complex power relations between the groups. Taking into account these power relations and with reference to previous initiatives for addressing intergroup relations, we propose a pedagogical approach that incorporates the tools of critical pedagogy to improve intergroup relations in social contexts such as Québec City. Pedagogical activities using this critical approach would lead students to challenge power relations and intergroup categorization between anglophones and francophones in Québec.
\end{abstract}

\section{Introduction}

"I see the English-speaking community of Québec like having two sides; you know, there is French and English speaking, and they don't really go together. So it's like a separation line.”

“...je trouve que les francophones et les anglophones sont séparés souvent, tu sais.”

From the mouths of high school students in Québec City, these words reflect a social reality prevalent for generations, the reality of two separate language groups, which have 
been called the Two Solitudes, in reference to Hugh MacLennan’s classic novel published in 1945. Times change and intergroup relations shift, some periods being characterized by more or less tension between francophones and anglophones in Québec. However, a generalized conception of a division between language groups persists through time. Such divisions in society influence and, as we will discuss, are influenced by educational institutions. In the context of divided societies, what is the role of the school in the (re)production of the collective identities of national minorities and majorities? How do students perceive these divisions and the role of the school? What strategies might educators use to address processes of linguistic categorization and relations between language groups?

The situation for anglophones in Québec is unique in that a language group that is the majority in North America, and dominant in many ways throughout the world, has become a de facto minority in a province devoted to protecting the French language and culture. In Québec City, the site of our research, mother-tongue English speakers make up only $1.46 \%$ of the population, with an additional $0.30 \%$ claiming both English and French as mother tongues (Statistics Canada, 2006 Census of Population). The relatively homogenous French milieu of Québec City contributes to dichotomous ingroup-outgroup relations, particularly between the francophone majority and anglophone minority. ${ }^{1}$

The Quiet Revolution in Québec in the 1960s brought about changes in relations between francophone and anglophone groups. In that period, language (more than religious or economic issues) became the principle point of conflict between the two language groups as a collective sense of identity emerged among the francophone majority in reaction to the growing sense of the fragility of French language and culture in America. The Charte de la langue française (Charter for the French Language), the primary legislative document in Québec’s language policy commonly known as Bill 101, was passed in 1977 establishing French as the only official language of Québec and, thus, as the compulsory language of instruction for primary and secondary public education. With the aim of integrating immigrant children into the French schools, Article 73 of the Charter limits access to English public schools to students who meet the following criteria: having a parent who is a Canadian citizen and who has received the majority of 
his or her education in English in Canada. A student may also have access to English schools if he or either of his siblings has received the major part of his education in English in Canada. Despite these access restrictions, Québec's English public schools have included growing numbers of students who have French as a mother tongue (with or without English). In Québec City, the proportion of francophones in English public schools is especially high, with mother-tongue francophones outnumbering anglophones two to one in 2005-2006 (Jedwab, 2007). These students may have gained access to the schools because of mixed marriages or because one of their parents had attended an English language school before Bill 101. It is also worth mentioning that in 1998, Québec's public school system was reorganized, transitioning from a religious structure (with protestant and catholic parallel networks) to a linguistic structure made up of French and English school boards emphasizing the linguistic barriers between the two networks.

This article examines how linguistic policy and administrative reform have contributed to the construction of linguistic boundaries between francophones and anglophones in Québec, a question that has received little attention from academics (McAndrew \& Proulx, 2000). A few recent studies have addressed the issue of identity construction for youth in the context of English schools (Gérin-Lajoie, 2011; GérinLajoie, in press; Magnan, 2010; Magnan in press; Pilote, Magnan \& Vieux-Fort, 2010; Vieux-Fort \& Pilote, 2010). However, identity construction for youth who have the right to English language education (a population that includes not only students whose mother tongue is English but also those with French or other languages as mother tongue) is an issue requiring further study. Indeed, given the role of the school in producing "national" identity (Thériault, 2007; Schnapper, 1994) and sustaining social cohesion (Durkheim, 1969), it is relevant to investigate the role of English language schools in the (re)production of linguistic boundaries between francophones and anglophones in day-today interaction.

Using a constructivist and interactionist approach to identity and ethnicity, we examine in this article the role of English language schools in the production of boundaries between anglophones and francophones in Québec. In the first part of the 
article, we present findings from two qualitative studies conducted with youth who attended English language schools in Québec, one conducted with 29 adolescents and the other with 33 young adults. Results show how the school system contributes to the (re)production of linguistic boundaries in the local context of Québec City. In the second part of the article, we opt for a critical perspective for exploring ways in which schools and educators can work with students to address issues of linguistic boundaries and conflict. Before moving on to the core subject, we present a brief historical context followed by the conceptual framework.

\section{Changing power relations between francophones and anglophones in Québec}

Throughout Québec’s history, interactions between francophones and anglophones have been embedded in political dynamics characterized by a struggle for power. Before the Quiet Revolution, the dominance of the English-speaking community in the province of Québec gave them the status of a superior, majority group even if they were a minority from a demographic standpoint. At that time economic power in Québec, and indeed throughout North America, was held primarily by British and Protestant anglophones. This financial elite contributed to the establishment of various institutions of English Québec: businesses, media, churches, associations, school boards, charities, etc. The economic hegemony held at that time by the British and Protestant merchant elite also translated into political power. Up until the 1960s, the anglophones of Québec were well represented in both federal and provincial political structures. Moreover, since the anglophones held economic power, they also dominated in the areas of social life where their interests were at stake, including the education sector. From World War II onward, however, there began a decline for the anglophones of Québec, a decline that would intensify with the Quiet Revolution. The English financial and business elite who had played a leading role in power relations would gradually move to the neighbouring province of Ontario.

Following the Quiet Revolution, power relations gradually reversed between francophones and anglophones. Various political events contributed to this shift, 
including the election of the Parti Québécois at the legislative assembly in 1976 (a party seeking independence for Québec) followed by the adoption of Bill 101 in 1977. Faced with the emergence of the "Québécois » identity and the establishment of French as the official language, the anglophones of Québec redefined themselves as a linguistic minority within the province of Québec. A decline in the anglophone population of Québec at that time could be seen not only politically but also demographically and economically. This period is marked by a defensive attitude by the English at the political level, an attitude linked to feelings of powerlessness (Stein, 1982). ${ }^{2}$

Currently in Québec, one can certainly say that francophones are in a process of majoritization, while anglophones are in a process of minoritization (McAndrew, 2010). Anglophones in Québec are worried about their ethnolinguistic vitality and are attempting to revitalize their institutions (Bourhis, 2008). They try to retain some power by preserving their institutional completeness (Breton 1964) and fostering their demographic vitality. Despite the social changes since the Quiet Revolution, francophones in Québec remain a "fragile majority" (McAndrew, 2010) given their location in anglo-dominant North America and their accommodation of a significant proportion of immigrants who speak languages other than French. It is within this context of power relations between the majority and minority that we analyze the construction of linguistic boundaries between the francophones and anglophones in Québec City.

\section{Ethnicity and intergroup relations}

Our conceptual framework is based on constructivist theories. Thus, our approach is not inspired by a functionalist or structuralist sociology in which ethnic identities are seen as mirroring the social structure. Nor is our perspective based on a substantialist approach in which ethnicity is viewed as a static and homogenous attribute inherent from birth. Rather, we consider ethnic boundaries to be the result of social interactions that evolve constantly through relations with other groups of people, relations that intensify either differentiation from or association with the Others (Dortier, 1998).

Our definition of ethnicity, following Weber (1978), focuses more on the process leading to the formation of ethnic groups - that is "communalization" - than on the 
description of ethnic groups and their objective characteristics. Weber (1978) defines ethnic groups as those human groups that entertain a subjective belief in their common descent because of similarities of physical type or of customs or both, or because of memories of colonization and migration; this belief must be important for the propagation of group formation; conversely, it does not matter whether or not an objective blood relationship exists. Thus, ethnicity refers to a common symbolism that members of a community imagine to define themselves (Anderson, 1983), a symbolism that can be constructed, reconstructed, and even deconstructed. The ethnic group is not defined by fixed attributes, by heritage, by a list of objective cultural characteristics or by a specific territory, but rather by these imagined reconstructions that take form through opposing interactions that are locally situated (Kaufmann, 2004).

Our framework for analysis is mostly inspired by the theories of anthropologist and ethnologist Fredrik Barth. Barth (1969) emphasizes how social actors create ethnic boundaries by classification and categorization mechanisms that take place during the interaction process. In his work, ethnicity is viewed as a dynamic phenomenon in which the definition of Us and Them is continually reconstructed to regulate interactions. According to Barth (1969), it is not social isolation that creates and maintains boundaries, but rather, day-to-day interactions and cultural contact. Ethnic boundaries are thus determined and maintained primarily by the interactions that take place between social actors. The identification categories that social actors choose to use determine the ways individuals will interact with each other, and these categorizations from the Out-group lead to a sense of shared culture by the In-group.

Barth (1969) does not focus on the group's cultural content but rather on the boundary that structures interactions. The enforcement of an ethnic boundary can be mainly explained by a constant dichotomization between members and non-members. Thus cultural differences are only relevant when they lead to categorization within dichotomous interactions between In-groups and Out-groups. In order to exist, the boundaries must be validated by the members of the groups in interaction with each other. Using this constructivist and interactionist approach to ethnicity, we analyze 
language-group boundaries and the role of the English school in the production of boundaries in two qualitative studies conducted in Québec City.

\section{Study 1: Linguistic boundaries in student drawings}

In the first study, student volunteers from two English high schools in Québec City were asked to draw and explain their view of the English community in Québec. The research was conducted with 29 secondary school students of whom 16 came from mixed anglophone-francophone families, 10 from francophone families, 2 from anglophone families, and one from a Chinese immigrant family. Over 2/3 of the students claimed a bilingual identity, while a few considered themselves francophone or anglophone only.

These drawings served to start a discussion and introduce a longer semi-structured interview dealing with topics such as their educational trajectories, linguistic practices and sense of identity. Rather than giving students a particular definition of community or categorizing them in a particular way, the interviewers sought to explore students' own definitions and positioning in relation to language groups in Québec. The drawings constituted the first research activity with the student participants, and in the first portion of the interview students were asked to explain their drawings. A complementary method in this qualitative research focusing on discourse analysis, drawing was chosen as a means for facilitating the expression of symbolic values and social representations or, in other words, as an expression of the world views of young people (Bourassa, 1999). For this paper, we have focused our attention on analysis of the drawings and the students' own elaboration on those drawings, searching for themes and reoccurring patterns in the students' representations.

Of particular interest in the drawings produced by these high school students is the recurrent theme of separation between language groups, pointing to the concept of boundary. Although asked to draw “your representation of Québec’s English-speaking community," many students drew that community in contrast to and distinct from the French-speaking community. While the anglophone community was sometimes positioned within the larger francophone community, a clear boundary still separated the two communities. A few students drew only the anglophone community, representing the 
closeness of the group or the network of activities within the group yet also implicitly separate from the French-speaking community. This theme, evident in the quotes at the beginning of this article, came up also in the interviews as students were asked to describe their drawing. As one student said: “C'est vraiment comme s'il y a[v]ait un mur entre les deux", bringing in the image of a wall between the two. ${ }^{3}$ Some students drew an actual barrier line between the groups. For example, in Figure 1, the groups are drawn as distinct entities, the English group smaller than the French group. Even though Dave ${ }^{4}$ positions himself in relation to both groups, the social construct of the duality between language groups remains.

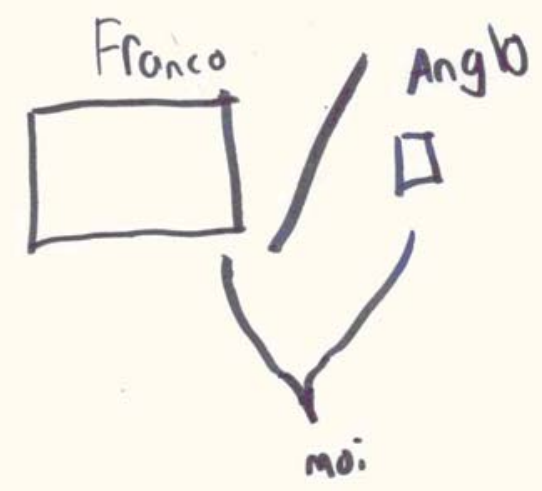

Figure 1: Dave’s Drawing

Elizabeth also draws the anglophone community as separate from the francophone community as shown in Figure 2. She talks about the two groups as distinct, even though she expresses some ambiguity in her own positioning. Although she has grown up in a francophone environment and is involved in mostly francophone activities, she has attended English institutions from preschool to high school. Student drawings and discussions of their own position in relation to the English-speaking community emphasized the boundaries between two distinct groups, regardless of whether students position themselves within a particular group or, as was more often the case, between the groups. 

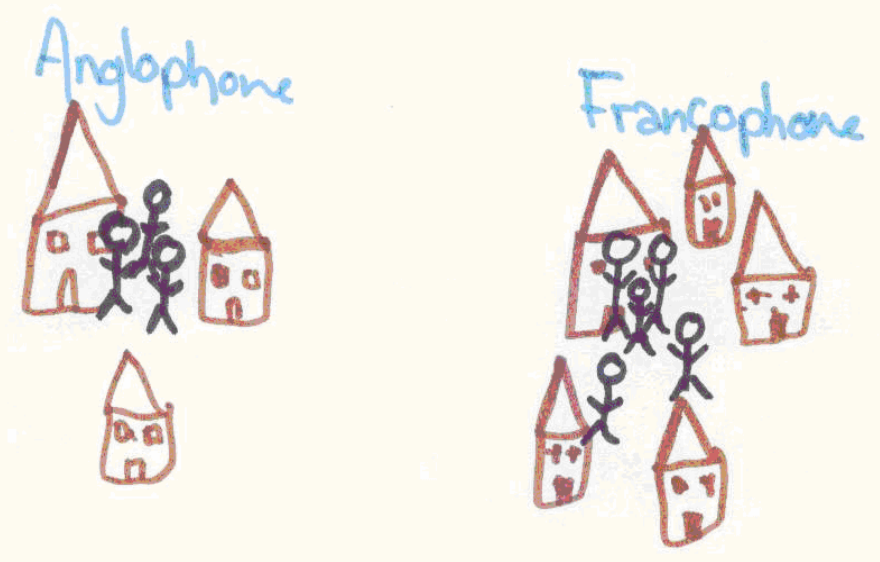

Figure 2: Elizabeth’s Drawing

Peter's drawing in Figure 3 shows the English community as a small entity within the broader French community, emphasizing its minority status. Although it is embedded in the French community, the English community is clearly distinct. In his description of the drawing, Peter goes on to describe the minoritization of the English-speaking community in Québec. Although the anglophones of Québec are assumed to be equal with the francophones, he says, they are in fact, a minority:

“C'est plus comme les anglophones au Québec, on est supposés d'être....pas la majorité, mais on est supposés d'être en équilibre avec les francophones. Mais avec tout ce qui se passe, on est, disons la minorité."

Peter's comment emphasizes the sense of inequality experienced by the English-speaking community in relation to the French majority. 


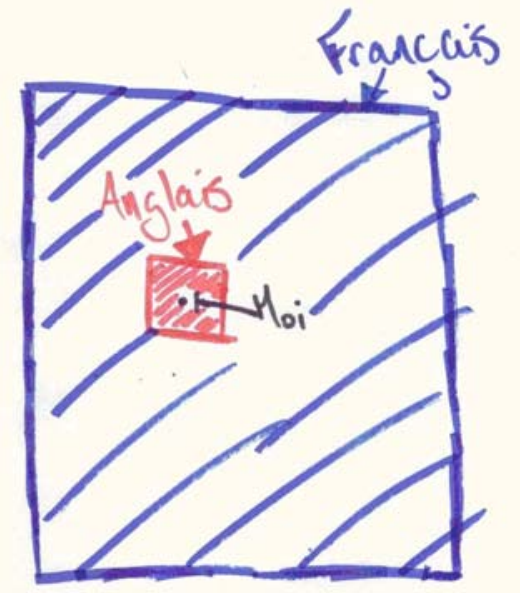

Figure 3: Peter's Drawing

Anne-Marie comes from a French-speaking family. She draws the anglophone and francophone communities as distinct groups, emphasizing their separation from one another but, like Dave, she places herself in between (See Figure 4). She describes her drawing, explaining that she has made separate sections because she finds that the francophones and the anglophones are often separated - that there are francophones who do not like or do not accept anglophones:

"Bien, moi j'ai fait un côté anglophone, un côté francophone-anglophone et un côté francophone parce que je trouve que les francophones et les anglophones sont séparés souvent, tu sais... il y en a des francophones qui n'aiment pas ou n'acceptent pas les anglophones."

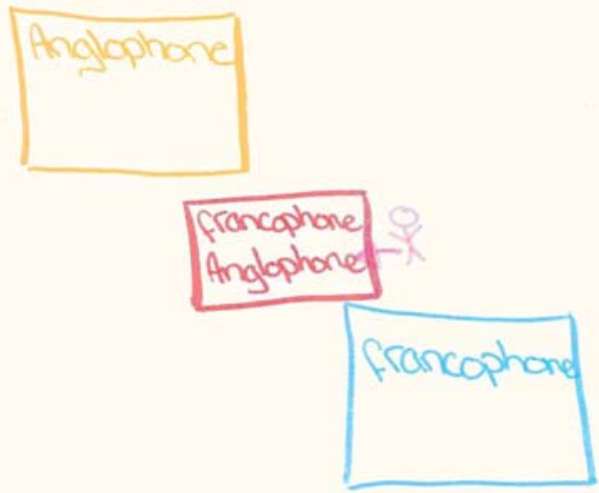

Figure 4 : Anne-Marie’s Drawing 
In describing intergroup tensions, Anne-Marie goes on to express her discomfort with discrimination against anglophone immigrants since she also attends English school and could be considered anglophone. When someone like an anglophone arrives in Québec, she says, they are labelled weird. She feels bad when she hears such things, not wanting others to think that way of her since she is in an English school:

“Quand quelqu'un comme un anglophone qui arrive au Québec, c'est comme: 'Ah bien là, il est bizarre.' Tu sais, moi je me sens mal, je suis dans une école anglaise, là, je ne veux pas qu'ils pensent ça de moi non plus ”

Placing herself on the francophone side, however, is too extreme, it seems, since she herself has nothing against anglophones. Rather, she places herself in what she calls the francophone-anglophone section because she goes to English school and actually likes the English:

“... Mais moi je me mets dans le côté francophone-anglophone parce que c'est sûr, je vais à l'école anglaise, donc, tu sais, quand même, moi je les aime les anglais, là!”

Since many of the students at the English schools in Québec, and many of those interviewed, come from francophone families, their frequent positioning of themselves as part of the English-speaking community points to the role of the English schools in shaping identity and defining community membership. Only a few students talked about the historical anglophone community. This can be seen as surprising since anglophones contributed in a major way in the shaping of Québec society as is still apparent today through topography, monuments, and institutions in Québec City. More important than heritage were descriptions of the anglophone community in terms of language skills, language use, and group activities. These understandings of the English-speaking community open up membership in the community to students whose home environments are completely French. Thus attendance at an English school, where English skills are improved and English activities attended, is sufficient for considering oneself, and being considered by others, anglophone.

Positioning within a particular community depends upon whom one is with and also to whom one is compared. For Mélissa, it is her francophone peers who have placed 
her in the category of anglophone, a category that she has not chosen for herself but that comes to her though attending the English school. In Québec, she says, someone could say that she is English, as at her job, for example :

“dans le Québec en tant que tel, quelqu'un pourrait dire que je suis anglaise, comme à ma job, par exemple. Mais je ne suis pas Anglophone. Je suis Québécoise. Mais vu qu'eux, ils sont carrément, ils ne parlent rien d'anglais, pour eux, je suis Anglaise.... Bien, comparée à eux, je suis Anglaise, mais comparé à ma culture, je n'ai rien d'Anglais dans ma famille! Dans ma famille, personne ne parle anglais."

Mélissa rejects an anglophone identity, claiming instead to be Québéquoise. The two, in her mind, are opposites. And yet she can understand why her colleagues have labelled her an anglophone. It is in reference to a linguistic criterion associated with the Québécois identity $^{5}$ that the anglophones (and by extension people who have certain abilities in English or who attend English schools) stand out as being different.

Student representations of the anglophone community highlight the boundaries separating the anglophone and francophone communities, however these are defined. Their positioning of themselves sometimes within but often between the two communities reflects the complexity of their identity construction as students at minority English schools in Québec’s “national capital.”

\section{Study 2: Linguistic boundaries in student memories of school}

In the second study, interviews were conducted with 33 young university students (from 20 to 29 years old) who had been educated at English high schools in Québec City and who had English as one of their mother tongues. About two-thirds of the respondents were from bilingual homes where one parent speaks English and the other speaks French.

In-depth individual interviews were conducted with respondents, covering the following topics: life history during childhood and adolescence, migration or nonmigration during the transitional years as a young adult, university trajectories, and sense of identity through time and transitions. We conducted a content analysis, coding the entire corpus thematically. Through the codification, we sought to identify how the sense of anglophone communalization in Québec took form in the discourse of respondents. 
Rather than linger on the representations and individual identities of each respondent, the analysis explored the general representations of inter-group boundaries. The aim was to describe a social world defined by a specific activity: that is to say, a social world defined by the institutional framework of the English language secondary schools of Québec. We also wanted to elaborate a core of common experiences with this group of individuals set apart by a common sphere of interaction.

The following observation can be made regarding our entire data set: our study demonstrates that the sole fact of attending school in the English language marks an identity boundary. This idea is consistent with Vieux-Fort and Pilote's (2010) conclusions regarding their study with students from English high schools in Québec City. In the eyes of the francophone majority, studying in English makes one an Anglophone as evident in these quotations: “aller à l'école de langue anglaise signifie être un anglophone”;“people look at you 'oh, tu vas à l'école anglaise'. It's like there a thing, like you are different”. Andrea, a 20-year-old student from a mixed linguistic background, feels the existence of this linguistic boundary - a boundary that takes place in the school context: "I think in anglophone schools you are already placed against everyone that's French”. The story she tells of her two-year experience at a French high school demonstrates clearly the importance of the school in creating linguistic boundaries

[By going to French school] I felt like I was more part of Québec because I was in French school and I was like "oh I am now like every other kid". You know, before you feel so different because you are a minority and when you are in an English school "oh, there is the minority". [At French school] I felt like a normal kid [...] I got more normal (laughs).

The institutional and structural framework of the separate English schools leads to common activities among, on one hand, the students from those schools operating in a minority context and, on the other hand, the students from French schools and from the francophone majority. Interactions among students from the English and the French schools generate categorization and tensions based on in-group and out-group relations: "there were fun things like going to Village des sports. When you'll have different schools like the French schools and English schools. And they'd hear the English school speaking English and you know 'les maudits anglais ${ }^{6}$ and all that”. Anthony tells how, 
in his childhood, groups from the English and French schools defined themselves against each other in competitions in the schoolyard: "when I was a child, up to grade 4, it was English and French together. On the same school yard, which was particularly unique because it'd be French against English for everything... it was still the old you know English versus French and the snowball fights... everything would be on these linguistic lines”. Sometimes the clashes between the schools take the form of confrontational relationships. The francophones from surrounding high schools, one student remembers, would come to do graffiti on the walls or to fight. The encounters were never very positive:

“Nous, quand on était à l'école, ce qui était francophone si on veut, c'est les polyvalentes d'autour. Quand ils venaient, c'était tout le temps pour nous faire des graffitis sur les murs ou pour se battre, puis tout plein d'affaires-là. C'était jamais super positif".

Taking the bus at the end of classes is also a context in which boundaries structure the interactions between members of the two school/linguistics groups: "just in the city bus, when we were going back home, there was always like 'ah you're the English kid'. And the rest of the kids were like 'ah we are the French kids'”. Speaking English on the bus, according to our respondents, can generate negative and sometimes aggressive reactions among students from the French schools, including derogatory labels and being told to "go home”: "être sur la bus, parler en anglais avec mes amis. Puis nous faire dire des niaiseries, puis genre 'retournez chez vous les hosties d'anglais"'. Sports tournaments between schools also seem to structure dichotomizing interactions between students from French-language schools and students from English-language schools:

They were always like "oh [je joue] contre les anglophones" ....and they sometimes assumed that we don't understand French which is completely retarded [...] and they would be like amazed that we could speak French like "non, c'est impossible you can't speak French, you go to English school”.

These interactions between the language groups generate among the students we interviewed from English schools a common experience in intergroup contacts, leading to a sense of belonging to a minority with its own values and its own culture - to a sense of 
community. Thus, the formal boundaries of the English school contribute to the sense of belonging to a language group. The students we interviewed, who had attended English schools, have come to see themselves (at least subjectively) as a distinct minority group characterized by a sense of cohesion, of everyone belonging: "it's always special... it's like there is a bond between you. Because you are a minority. There is like a little special thing where it is like 'tout le monde se tient"'. The common interactional experience with the majority francophone "Other" creates among them a sense of belonging to the anglophone group of Québec. Nathalie explains well how this sense of belonging to the “anglophone community” of Québec takes shape, notably through the shared experience of the English school and the out-group sense of "otherness" that this created : "When you go to English school in Québec, you know you are different, you know that there is very few of you... you're used to people making fun of the fact that you speak English or commenting on it... and you get used to it and you expect it”.

The young people we interviewed also feel that they have their own values, values that take shape in opposition to the francophone Other. The importance given to family and the respect of tradition are the values most often mentioned by respondents; according to them, their French counterparts do not give much importance to these values. Along with these sentiments of forming a "community”, there is also a developing perception of having a specific school culture. From talking with their friends attending French schools or in attending a French school themselves at some point in their schooling, the young people we interviewed have the impression that English schools give higher value to academic achievement, involvement in sports, and the values of respect and school spirit.

In sum, the data from this research reveal that the sense of alterity or otherness experienced by young people who have attended English schools leads to the construction of linguistic boundaries in the local context of Québec City. The institutional and structural framework that makes up Québec's English school network serves to foment dichotomous interactions between students from these minority-language schools on one side and students from the French schools on the other - interactions that build a 
boundary between them. And this boundary seems to take shape through the ways the francophone Other perceives the students attending English schools in Québec.

\section{Pedagogical strategies for addressing intergroup relations in Québec}

In light of the linguistic boundaries erected between francophones and anglophones in Québec, some initiatives for intergroup reconciliation have been brought forward since the 2000s. These projects are mostly inspired by the theory of intergroup contact in social psychology. This theory advocates that, under certain favourable circumstances, more contact between members of different groups leads to a better understanding of one another and less discrimination between the groups (Côté \& Mettewie, 2008).

In 2003-2004, an action research project was conducted with the goal of problematizing the boundaries between anglophones and francophones in Québec (McAndrew et al., 2003). This one-year project paired 15 students from two universities in Montreal, one French-language and one English-language university. These students were in teacher training and were mostly future secondary-school teachers in the fields of history, geography and citizenship education. The project aimed primarily to explore the perceptions of the students regarding intergroup relations in Québec. The francophone and anglophone students were to discuss together their perceptions and develop projects related to this issue, projects that they could later implement in their own classrooms. A bilingual video was produced to sensitize students to the role of the school in promoting positive contact between francophones and anglophones (McAndrew, 2010: 87). At the end of this collaborative project, some students talked about an increased awareness of the « dangers » of categorizing people and of linguistic stereotypes constructed through the media.

Another example is the Projet d'échanges linguistiques intra-Québec (PÉLIQAN) established in 2007 by Québec's Ministère de l'Éducation, du Loisir et du Sport through an active collaboration with a team of researchers lead by Benoît Côté, professor of psychology at the Université de Sherbrooke. This project, which involves matching students from French and English elementary and secondary schools in the province of Québec, provides opportunities for interactions between these two groups of students 
with the goal of improving connections and communication between anglophones and francophones (Côté, 2009; Pagé et al., 2007).

Taking a different approach from the projects above, yet grappling with the same issues, Zanazanian (2011; in press (b)) has more recently suggested a project for the inclusion of Québec anglophones in the official Québec history curriculum. By interviewing francophone history teachers, Zanazanian (2008) discovered that few of them were preoccupied by the inclusion of Québec anglophones in the content of history courses. In light of these research findings, he proposes to revise history lessons so that teachers can convey an open and inclusive identity in Québec. By acknowledging strained power relations between the francophones and anglophones, Zanazanian wishes to bring about change between the two solitudes of Quebec society.

\section{Applying critical pedagogy within the linguistic divide}

The boundaries evident between language groups in Québec City, as illustrated in student drawings and memories, reflect complex power relations between the groups. Historical struggles for economic, social, and political power have shaped the school system and set the stage for the social division experienced by current students. Taking into account these power relations and in the wake of the above initiatives, we propose a pedagogical approach that incorporates the tools of critical pedagogy to improve intergroup relations in social contexts such as Québec City. This approach would lead students to challenge power relations and intergroup categorization between anglophones and francophones in Québec. The focus would be to develop a critical awareness of how relations of power are being entertained between anglophones and francophones in Québec as well as how stereotypes between the groups are constructed. This awareness goes beyond understanding relations between divided social groups to understanding the role of language in creating and perpetuating those divisions. Beyond fostering positive interactions, we seek to engage educators and students more actively and through a critical perspective, focusing attention on the powerful social consequences of reproducing linguistic boundaries. 
Raising awareness of the power of language, according to Fairclough (1989), is "the first step towards emancipation," as he aims to "increase consciousness of how language contributes to the domination of some people by others” (p. 1). He describes the power of language in perpetuating common-sense assumptions, assumptions that are shaped by relations of power. Heller and Martin-Jones (2001) use Bourdieu's (1991) terminology and his understanding of language as a mechanism of power to discuss the symbolic domination involved in language choices, especially in education settings. There is not a simple connection between language on one hand and economic and political advance on the other. Rather, particular languages come to be viewed as "legitimate languages” with implications for access to resources and for the perceived naturalness of social order. Education is a site for the building of such assumptions, social identities and power inequalities. The ways that people make language choices and thus manage language resources become ritualized, "permitting the construction of dominant discourses that reproduce relations of power...and hence to the unequal distribution of resources” (Heller \& Martin-Jones, 2001: 11).

In the Québec context, it is not only dominant language that is legitimized through school but also language-based division that is legitimized through the school system. Yet the system was intended to protect the rights of anglophones, a group that is recognized as an historical minority. Working from within the system, educators can find ways to address discourses of division between anglophones and francophones. For precedents in the use of awareness-raising strategies to focus on power relations, we turn to the work of critical educators.

Freire's (1970) pedagogical approach seeks to address power issues in society through awareness-raising and dialogue. Proponents of the critical pedagogy movement critique schools for their role in the reproduction of power relations, considering the school to be an institution that tends to reproduce the dominant culture through curriculum and pedagogical practice. The basic presumption is that school is not neutral culturally or politically. Critical pedagogy is also about social and human transformation. At one level, school can be seen as an institution where school stakeholders can contribute to social change with a view towards justice and equality (Giroux, 1983). At 
another level, critical pedagogy advocates individual human transformation through stimulating the intellect of teachers, students and members of the global society. This also addresses the development of critical awareness and reflexivity, questioning the objectivity of knowledge imposed by the dominant elite. It is particularly through development of a reflexive and democratic pedagogy that teachers and school administrators can contribute to social justice. Rooted in dialogue, this pedagogy focuses on the perspectives of students with a view towards empowerment and the coconstruction of knowledge (Kincheloe, 2008). Critical literacy practices have been used in various ways in relation to language, including critical language awareness, which focuses learner awareness on the power of language choices and the use of language to promote particular views (See Janks, 2010).

Just as the research highlighted in the two studies earlier in this article have prioritized the perspectives of students for building knowledge, a critical pedagogy approach to language-group relations would begin with dialogue among students and teachers, drawing on the experiences and concerns of each and bringing into focus the power dynamics at play in intergroup relations. Historical groundings for power structures would be discussed. Multiple layers would need to be explored, contrasting and examining the roots of the power of the English language in North America and globally; the power of French in Québec, and particularly in Québec City; and the impact of these on group relations. The various roles of English and French within the school could be explored as the use of language demonstrates and recreates power differences. Dialogue regarding language and power could also begin with naming the various values and stereotypes associated with each language and drawing attention to the ideologies of mono-, bi-, and multilingualism. Students could then explore how their own identities are constructed in light of power dynamics within the Québec City context.

The development of pedagogical activities using this critical approach could take various forms. We envision a project with several tiers. First, scholars would work with teachers, using similar awareness-raising and dialogue strategies as those proposed for use with students and accompanying teachers in designing lessons and activities. Teachers would then work with their students, encouraging dialogue on language and 
power issues and partnering with students in planning their own projects. At this stage scholars could work with teachers in tracking and evaluating their strategies through action research. An additional tier, or perhaps part of a student-planned project, could include joint activities and dialogue between students at French and English schools. Goals for the students would be that they: 1) become aware of historical power relations between anglophones and francophones, 2) become aware of the role of the Québec school system in the maintenance of boundaries between francophones and anglophones, in particular through the experience of intergroup categorization, 3) explore identity construction, 4) express their views on these issues, 5) develop a joint project leading to a desired social change.

The students whose drawings and quotes are highlighted in the above studies are certainly aware of the boundaries that divide the anglophones and francophones of Québec City. Should they not have the opportunity to explore the roots and consequences of those divisions in a safe and empowering environment of dialogue that positions them as actors in the situation? Bringing into focus power relations between anglophones and francophones from a critical pedagogy point of view, as well as promoting intergroup encounters with the goal of overcoming discrimination and stereotyping, would provide an opportunity to promote social change. Critical dialogue among students and teachers would promote social reflection on the dichotomous view of language groups in Québec, planting the seeds for change.

\section{References}

Anderson, B. (1983). Imagined communities: Reflections on the origin and spread of nationalism. London: Verso.

Barth, F. (1969). Ethnic groups and boundaries: The social organization of culture difference. London: George Allen \& Uwin.

Bourdieu, P. (1991). Language and symbolic power. Cambridge: Polity Press.

Bourhis, R. Y. (Ed.) (2008). The vitality of the English-speaking communities of Quebec: From community decline to revival. Montreal, Quebec: CEETUM, Université de Montréal.

Bourassa, M. (1999). Le dessin, mieux comprendre pour mieux intervenir. Canadian psychology/Psychologie canadienne, 38(2): 111-121.

Breton, R. (1964). Institutional completeness of ethnic communities and the personal relations of immigrants. American Journal of Sociology, 70(2): 193-205. 
Côté, B. (2009). PELIQ-AN 2008-2009: Rapport de recherche. Rapport final soumis au ministère de l'Éducation, du Loisir et du Sport du Québec. Université de Sherbrooke.

Côté, B, \& Mettewie, L. (2008). Les relations entre communautés linguistiques en contexte scolaire et communautaire: regards croisés sur Montréal et Bruxelles. Éducation et francophonie, 36(1) : 5-24.

Dortier, J.-F. (1998). L’individu dispersé et ses identités multiples. In J.-C. RuanoBorbalan (Ed.), L’identité : L’individu, le groupe, la société (pp. 51-53). Auxerre et Paris : Science humaines et P.U.F.

Durkheim, E. (1969). L'évolution pédagogique en France, 2e édition, Paris: Presses universitaires de France (1938).

Fairclough, N. (1989). Language and power. London: Longman.

Freire, P. (1970). Pedagogy of the oppressed. New York: Continuum Publishing.

Gérin-Lajoie, D. (2011). Youth, language and identity. Toronto: Canadian Scholars' Press.

Gérin-Lajoie, D. (in press). Analyse comparative du rapport à l’identité chez les jeunes des commuanutés de langue officielle au Canada. Francophonies d'Amérique.

Giroux, H. A. (1983). Theory and resistance in education: A pedagogy for the opposition. London: Heinemann Educational Books.

Heller, M., \& Martin-Jones, M. (2001). Voices of authority: Education and linguistic difference. Westport, CT: Ablex Publishing.

Janks, H. (2010). Language, power and pedagogy. In N. Hornberger \& S. McKay (Eds). Sociolinguistics and Language Education (40-61). Clevedon: Multilingual Matters.

Jedwab, J. (2007). Follow the leaders: Reconciling identity and governance in Quebec's anglophone population. International Journal of the Sociology of Language, 185: 71-87.

Kaufmann, J.-C. (2004). L'invention de soi: une théorie de l'identité. Paris: Hachette littératures.

Kincheloe, J. L. (2008). Critical pedagogy primer, 2nd edition. New York: Peter Lang.

Magnan, M.-O. (2010), Franchir les frontières scolaires, franchir les frontières identitaires? De l'école anglaise vers l'université francophone au Québec, Ethnologies: Revue de l'Association Canadienne d'Ethnologie et de Folklore, 31(2): 289-312.

Magnan, M.-O. (in press), Les frontières linguistiques à Québec: le rôle des interactions scolaires, Canadian Ethnic Studies/Études ethniques au Canada.

MacLennan, H. (1945). Two solitudes. New York: Duell, Sloan and Pearce.

McAndrew, M. (2010). Les majorités fragiles et l'éducation. Montréal: Presses de l'Université de Montréal.

McAndrew, M., \& Proulx, J-P. (2000). Éducation et ethnicité au Québec : un portrait d'ensemble. In M. McAndrew \& F. Gagon, (Eds.) Relations ethniques et éducation dans les sociétés divisées : Québec, Irlande du Nord, Catalogne et Belgique, Paris and Montréal: L’Harmattan, 85-110. 
McAndrew, M., Mitchell, C., Côté, B. \& Kirk, J. (2003). Creating action space for cultural collaboration, Rapport de recherche. Canada: Ministère du Patrimoine Canadien.

Pagé, M., Côté, B., \& Lasry, J.-C. (2007). Les contacts entre jeunes francophones et anglophones dans l'Île de Montréal, rapport de recherche non publié, CEETUM.

Pilote, A., Magnan, M.-O., \& Vieux-Fort, K. (2010). L’identité linguistique et le poids des langues: étude comparative entre des jeunes de milieu scolaire francophone au Nouveau-Brunswick et anglophone au Québec. Nouvelles perspectives en sciences sociales. Revue internationale de systémique complexe et d'études relationnelles, 6 (1), 65-98.

Schnapper, D. (1994). La communauté des citoyens. Paris: Gallimard.

Statistics Canada. (2007). Québec, Québec (Code2423027) (table). 2006 Community

Profiles. 2006 Census. Statistics Canada Catalogue no. 92-591-XWE. Ottawa.

Released March 13, 2007.

http://www12.statcan.ca/census-recensement/2006/dp-pd/prof/92-

591/index.cfm?Lang=E (accessed July 7, 2011).

Stein, M. (1982). Changement dans la perception de soi des Anglo-Québécois. In G.

Caldwell \& E. Waddell (Ed.). Les Anglophones du Québec: de majoritaires à minoritaires, (pp. 111-130). Québec: IQRC.

Thériault, J-Y. (2007). De l'école de la nation aux écoles communautaires ou de l'école d'en haut à l'école d'en bas. In J.-Y. Thériault (Ed.) Faire société. Société civile et espaces francophones (pp. 191-209). Sudbury : Prise de Parole.

Vieux-Fort, K., \& Pilote, A. (2010). Représentations et positionnements identitaires chez des jeunes scolarisés en anglais à Québec : explorations méthodologiques.

Glottopol. Revue internationale de sociolinguistique, no. 16, 81-99. Available : http://www.univ-

rouen.fr/dyalang/glottopol/telecharger/numero_16/gpl16_07vieuxfort_pilote.pdf

Weber, M. (1978). Economy and society : an outline of interpretive sociology, Vol 1.

Berkeley and Los Angeles: University of California Press.

Zanazanian, P. (2008). Historical consciousness and the French-English Divide' among Quebec history Teachers. Canadian Ethnic Studies, 40(3): 109-130.

Zanazanian, P. In press. Historical consciousness and the structuring of group boundaries

: A look at two Francophone school history teachers regarding Quebec's

Anglophone minority. Curriculum Inquiry.

Zanazanian, P. (2011). Towards developing an "Anglo-Québécois" information resource book for school history teachers in Quebec: Thoughts from a qualitative study. Journal of Eastern Townships Studies/ Revue d'études des Cantons-de-l'Est. 36 (Spring/Printemps):

69-95.

1 We use the terms "anglophone" and "francophone" as they are frequently used in Canada's and Québec's linguistic policies. This terminology is also widely used in the media and among social actors. The alternative terms, English-speaking or French-speaking, are sometimes used, but they focus attention on the language spoken, which is only one of several criteria that set the groups apart as distinct.

2 Some anglophones have contested their minoritization, using various means to assert their claims. Several associations emerged (Participation Québec 1976, Positive Action Committee 1976, Freedom of

Bellaterra Journal of Teaching \& Learning Language \& Literature. 4.3

(Sept-Oct 2011): 1-23. ISSN 2013-6196. 
Choice Movement 1978, Council of Québec Minorities 1978, Alliance Québec 1982). They claimed a revision of the language laws in Québec and brought forward the value of bilingualism. Their demands led to the creation of a political party in 1989: le Parti Égalité.

3 For the sake of convention we use italics to set apart French phrases, even while we notice that these practices also emphasize boundaries.

4 In order to preserve the identity of participants, all of the names are pseudonyms.

5 The use of the term "Québécois" as opposed to "Quebecker" carries an obvious linguistic implication, associating French with Québécois identity.

6 "Les maudits anglais" is a pejorative French expression used to categorize English-speaking people in Québec.

\section{Author References}

Annie Pilote is Associate Dean of Research and Graduate Studies at the Faculté des sciences de l'éducation, Université Laval, Québec (Canada). She is a researcher with the Centre de recherche et d'intervention sur l'éducation et la vie au travail and the Observatoire Jeunes et Société. Her research projects deal mainly with youth, identity and educational paths among linguistic minorities. She also specializes in intercultural education and ethnic relations. She recently coedited with Silvio Marcus de Souza Correa a book focusing on minority youth in Canada and Brazil, Regards sur l'identité des jeunes en contexte minoritaire (2010).

\section{Email: Annie.Pilote@fse.ulaval.ca}

Marie-Odile Magnan is assistant professor at the Department of Educational Administration and Foundations at the University of Montreal. She holds a Ph.D. in sociology from Université Laval. She has worked extensively on linguistic issues and minority-language education in Quebec and in Canada. She has mostly focused her research on the role schools have on youth identity construction and linguistic socialization.

Email: marie-odile.magnan@umontreal.ca

Cynthia Groff is a post-doctoral researcher at Université Laval in association with the faculté des sciences de l'éducation and the Centre de recherche et d'intervention sur l'éducation et la vie au travail. She holds a Ph.D. in Educational Linguistics from the University of Pennsylvania. Her research on issues of language, education, identity, and empowerment highlights the voices of linguistic minorities, including Kumauni young women in North India and Anglophone youth in Québec City.

Email: cgroff@alumni.upenn.edu 